Kiss Tibor r. alezredes:

\title{
A TERRORIZMUS ARCULATVÁLTÁSÁNAK HATÁSA A HELYSZÍNI REAGÁLÓERŐK FELKÉSZÍTÉSÉRE
}

DOI: $10.35926 / \mathrm{HSZ} .2021 .5 .2$

ÖSSZEFOGLALÓ: A terrorizmus arculata, a terrorizmus különböző fajtáihoz, illetve formáihoz kapcsolódó cselekmények jellege jelentős változáson ment keresztül az elmúlt évtizedekben. Ezek hatásai - mint azt az elmúlt évek tragikus nyugat-európai eseményei is mutatják - elérték térségünket, és a súlyos, sok áldozatot követelő terrorista merényletek bekövetkezésének valószínüsége is megnőtt. A végrehajtott támadások fókuszában már nem túszejtések és követelések állnak, hanem elsősorban aktívlövész-szituációk és öngyilkos robbantások. Ezeknek a cselekményeknek a jellege nagyban eltér a korábbiaktól, igy a terrorcselekmények helyszínein bevetett reagálóerők elsődleges tevékenységének a gyors, határozott és a lehetö legpontosabb végrehajtása még nagyobb jelentőséggel bír. A támadások megelőzésére, elhárítására és a veszteségek minimalizálására irányuló intézkedések nagyon magas szintü felkészültséget és naprakész ismereteket kivánnak az azt végrehajtó állománytól, így folyamatos felkészitésük minősége szempontjából az aktuális trendek alapos tanulmányozása és ismerete nem elhanyagolható. Az érintett állomány képzése, felkészitése és folyamatos, gyakorlatorientált továbbképzése ennek a feladatnak a vonatkozásában - csakúgy, mint minden más területen - széles körü, több összetevőből álló tréninget igényel.

KULCSSZAVAK: terrorizmus, terrorcselekmények, aktívlövész-szituáció, öngyilkos merényletek, helyszíni reagálóerők

\section{BEVEZETÉS}

A 2020 novemberében Bécs belvárosában történt események ismét rávilágítottak a terrorcselekmények végrehajtásának változó jellemzőire. Mint ismeretes, a támadás megközelítőleg kilenc perce alatt az elkövetö - miközben folyamatosan mozgott - válogatás nélkül nyitott tüzet a belvárosi szórakozóhelyek vendégeire és az utcán tartózkodókra, majd az odaérkező rendörökre, és ennek következtében négyen életüket vesztették, további huszonkét személy pedig megsebesült (köztük egy rendör - súlyosan).

A támadó 20.00 óra körül kezdett lövöldözni, majd 20.09-kor az osztrák rendörség bécsi különleges szolgálatának (WEGA ${ }^{1}$ ) két odaérkező tagjával tüzharcba keveredett, melynek során a terrorista életét vesztette.

Ez a támadás - mind az elkövető motivációi, mind az elkövetés jellege tekintetében illeszkedik abba a folyamatba, amely az elmúlt években Nyugat-Európában megkezdődött,

1 Wiener Einsatzgruppe Alarmabteilung. 
és melynek fenyegető jelenlétével egyértelmüen számolnunk kell többféle nézőpontból is. Ez a sorrend azonban számos változást is mutat az ezredforduló előtti időszakhoz képest, amiről a későbbiekben bővebben szót ejtek.

A terrorizmus elleni harcban érintett erök, szolgálatok, a terrorcselekmények helyszínén az életek és anyagi javak mentésében részt vevő szervezetek részéről ezeknek a változásoknak és trendeknek az alapos ismerete elengedhetetlenül fontos tevékenységük hatékonyságának és saját biztonságuk növeléséhez. Ehhez feltétlenül hozzátartozik egy olyan felkészítési, képzési rendszer létrehozása és működtetése, amelybe folyamatosan integrálják az elmúlt évek terrorcselekményekkel összefüggő elméleti ismereteit és a gyakorlati tapasztalatokat.

Ezzel párhuzamosan ugyancsak szükségesnek tartom a polgári lakosság és a különféle polgári, illetve „civil” - nem honvédelmi, rendvédelmi, nemzetbiztonsági - szervezetek, intézmények és azok vezetőinek és munkatársainak felkészítését is, hiszen alapvetően ők a terrorcselekmények talán leggyakoribb célpontjai, érintettjei, illetve a cselekmények általában rendkívül erős hatást gyakorolnak rájuk. Fontos, hogy legyen egy reális képük a terrorcselekmények mai jellegéröl, mivel ennek ismerete megalapozhat egy biztonságtudatos magatartást és megfelelő szituációs éberséget, ami adott esetben a lehetőség szerinti higgadt reagálást és ezzel a túlélést is jelentheti, valamint nagyban segítheti a hatékony együttmüködést a reagálóerőkkel.

A terrorizmus arculatváltásának rövid áttekintésével szeretnék rávilágítani arra, hogy napjainkban a változások a korábbinál gyorsabban és nagyobb mértékben gyakorolnak hatást a felkészítési, képzési rendszerekre, melyek gyors és átfogó megoldásokat igényelnek egy esetleges terrortámadás pusztító hatásainak elhárítása vagy minimalizálása érdekében. Véleményem szerint a terrorizmus arculata az elmúlt évtizedekben megváltozott. A változás megértéséhez elengedhetetlenül szükséges egy rövid történeti áttekintést végezni, így láthatóvá válik, hogy a modus operandi hogyan változott, és a terrorizmus mely típusai kerültek előtérbe a 21. század első évtizedeiben.

Kiss Zoltán László ${ }^{2}$ „A terrorizmus elleni küzdelem szociológiai természetű kihívásai” címü tanulmányában a terrorizmus következő definícióját tekinti leginkább használatosnak: „Az eröszak szándékos alkalmazása, illetve azzal történö fenyegetés a polgári lakossággal, illetve civil célpontokkal szemben meghatározott politikai célok elérése végett.”" $\mathrm{A}$ fenti gondolatsor mentén a terrorizmust elsősorban egy aszimmetrikus viszonyrendszerben a gyengébb fél által alkalmazott taktikának, eljárásmódnak tekintem, amely stratégiai szintü politikai célok, hatások elérését célozza - és amit azzal egészítenék ki, hogy melynek eröszakos eszközei és módszerei elsősorban a polgári lakosság, illetve civil célpontok ellen irányulnak.

Az általánosan jellemzö, demonstratív végrehajtások vagy azok kilátásba helyezése a politikai vezetés, illetve a társadalom minél szélesebb köre felé közvetített „üzenet” a terroristák részéröl. A média szerepének felerősödésével ez az „üzenet” már egyre gyorsabban és egyre nagyobb méretekben ér célba, tehát kijelenthető az is, hogy a nagy médiavisszhang viszonylag alacsony kockázat vállalásával érhető el.

2 Prof. dr. Kiss Zoltán László ezredes, a Nemzeti Közszolgálati Egyetem Hadtudományi és Honvédtisztképző Kar professzora, szociológus.

3 Kiss Zoltán László: A terrorizmus elleni küzdelem szociológiai természetủ kihívásai. Hadtudomány, 2005/4., 182-187. http://mhtt.eu/hadtudomany/2005/4/2005_4_31.html (Letöltés időpontja: 2021. 01. 06.) 
A terrorizmus brutális cselekményei - az ártatlan emberek ellen alkalmazott halálos erőszak, valamint az anyagi javak rombolása - demoralizálják a lakosságot, és az nyilván nyomást gyakorol a politikai vezetésre - ez tehát a terrorizmus egyszerü és pusztító logikája.

Ez a logika és ez az eljárásmód nem új keletü, miként az sem, hogy akik terrorcselekményeket követtek vagy követnek el, azok a legtöbb esetben azt állítják, hogy valamely politikai, vallási, etnikai vagy morális ügy érdekében cselekedtek, illetve cselekszenek. Így jellemzően az elkövetők felhatalmazzák magukat az erőszak alkalmazására a „magasabb rendü cél" érdekében.

Ezekből az eszmékből, eszmerendszerekből, ideológiákból a terrorizmus történelme alatt nagyon sok akadt, ennek megfelelően a terrorizmus az ideológiai szempontrendszere alapján is osztályozható. Nézzük a legjellemzőbbeket:

- politikai ideológiák: idesorolom elsőként a különböző politikai szélsőségeket (szélsőbaloldali és szélsőjobboldali szervezeteket, anarchista, nihilista csoportokat);

- szélsőséges vallási ideológiák: az alapja jellemzően a hit szélsőséges értelmezésében keresendő, és bár kétségtelenül napjaink egyik nagy fenyegetését az iszlám indíttatású terrorizmus jelenti, meg kell említenünk, hogy - nem kis számban - léteznek más vallások által átitatott szélsőséges csoportok is;

- etnikai és nemzeti függetlenségi ideológiák: lényegében a politikai ideológiákhoz tartozó, de mégis külön kezelendő kategória, mely politikai-filozófiai töltetét tekintve talán a legtágabb;

- tematikus: alapvetően azok a csoportok tartoznak ide, amelyek különböző politikai, gazdasági vagy társadalmi vonatkozású - sokszor erkölcsi, morális - céljaik elérése érdekében olyan erőszakos módszereket alkalmaznak, amelyek már megvalósítják a terrorcselekmény tényállását, kimerítik a terrorizmus fogalmát (ilyenek lehetnek a különböző környezetvédelmi, globalizációellenes csoportok is).

A fentieken túl, természetesen a terrorizmust - mivel az egy sok összetevőből álló, komplex rendszernek tekinthetö - több szempont szerint osztályozhatjuk, ${ }^{4}$ melyekre most jelen tanulmányom terjedelmi korlátai miatt nem kívánok részletesen kitérni. Áttekintésünk vonatkozásában alapvetően az alkalmazott eszközök és módszerek, a célkiválasztás mechanizmusa bír nagyobb jelentőséggel, melyeket a későbbiekben konkrét korszakok összefüggésében részletezek.

\section{A TERRORIZMUS A KEZDETEKTŐL AZ 1970-ES ÉVEK KÖZEPÉIG}

Mint arra a fentiekben már utaltam, a terrorizmus nem a 21., de még csak nem is a 20. század terméke. A mai értelemben vett terrorizmusra találhatunk példákat a történelmi időkben, így akár az Ószövetségben leírt Judit és Holofernész ${ }^{5}$ történetét is tekinthetjük ennek, de nézzünk ehhez a megközelítéshez is néhány konkrét példát.

Már a 11. századtól tudunk olyan jól szervezett, felfegyverzett és konspirált terrorista támadások elkövetésére kiképzett csoportokról, amelyek célja félelem- és zavarkeltés volt. Az egyik legismertebb ilyen csoport a perzsa Haszan-i Szabáh ${ }^{6}$ által létrehozott izmaelita szekta, amely aszaszinek néven vált híressé-hírhedtté. Tagjai nevüket egyes vitatott források

\footnotetext{
Kiss: i. m.

5 Holofernész: Judit könyvének (katolikus Biblia egyik deuterokanonikus könyve) elbeszélése szerint a ninivei uralkodó, Nabukodonozor hadvezére volt, aki hadjáratot vezetett Izrael ellen.

6 Haszan-i Szabáh (kb. 1034-1124) karizmatikus síita vallási vezető volt.
} 
alapján az arab hasisin (jelentése hasisfogyasztó) szóból eredeztetik, mely a gyilkosságokra, támadásokra való felkészülés során történő kábítószer-használatra utal.

Az igazi szembenézés a jelenséggel a középkorban vette igazi kezdetét. A társadalmi jogállás születési alapon történő meghatározása alapvetően magában hordozta a népesség többségének elnyomását, esetenkénti terrorizálását. De a terror középkori megjelenési formájának tekinthető az inkvizíció intézménye is, amely egy, a katolikus egyház által müködtetett sajátos jogi intézmény volt.

A történelmi idök terrorjellegü cselekményei számos hadjáratot is kísértek, ahol nem feltétlenül érvényesültek a romantikus regények lovagi erényei. A Szentföldre vezetett keresztes hadjáratok során mindkét fél számos kegyetlen cselekménnyel igyekezett bizonyítani elhivatottságát a győzelem kivívására, valamint megtörni az ellenfél morálját, összezúzni támogatottságát, és ezzel a másik fölé kerekedni. Hasonló könyörtelenséggel zúdultak Európára a mongol-tatár hadak is, amelyeknek a kegyetlenségéről szóló históriák sokfelé megelőzték érkezésüket.

A középkori terrorizmus első tömeges megnyilvánulására Dél-Franciaországban került sor 1209-1226 között, ahol a francia nemesek pápai parancsra tízezrével mészárolták le az eretneknek nyilvánított katharokat. ${ }^{7}$

A fentiekben említett cselekmények azonban ma már más jogi kategóriába, tényállásba sorolhatók (genocídium, egyéb háborús büncselekmények), és mélyebb jogi értelmezés vagy elemzés nélkül megállapíthatjuk, hogy a mai értelemben vett terrorizmus alatt alapvetően mást értünk.

A terror szó modern jelentése új értelmezést nyert a francia forradalom során a Robespierre $^{8}$ nevével fémjelzett jakobinus diktatúra alatt is, és egyfajta új eredetet jelent a la terreur, mely állami terror során a kivégzettek száma tizenhárom hónap alatt megközelítette a negyvenezer föt.

Mintegy százötven évvel ezelőtt, a 19. század utolsó évtizedeiben bukkant fel a terrorizmusnak az a formája, mely során csoportok, politikai irányvonalak államok, rendszerek megdöntésére vagy megszüntetésére törekedve követtek el merényleteket. Több szakértő, köztük David C. Rapoport, ${ }^{9}$ a Kaliforniai Egyetem (University of California) professzora innen keltezi a modern terrorizmus kialakulását, hozzátéve, hogy a cselekmények jellege ekkor még inkább világi és nem vallási, más megközelítésben pedig inkább lokális, semmint nemzetközi kiterjedésü.

Idesorolhatjuk az Oroszországban a cárok meggyilkolását tervező titkos szervezeteket, köztük a Narodnaja Volja (Népakarat) nevü szervezetet, amely II. Sándor cár ellen hajtott végre sikeres merényletet 1881. március 13-án egy, a cár hintója alá dobott bombával. De további anarchista csoportok is felbukkantak (bakunyinisták, blanquisták), melyek az állam destabilizálása céljával követtek el merényleteket.

A két világháború között már több alkalommal is foglalkoztak a terrorizmus kérdésével jogi és büntetőjogi szinten is. Egy 1930-ban Brüsszelben elöterjesztett, öt cikkelyből

\footnotetext{
Katharoknak (vagy kataroknak) nevezték a 10. század közepén Dél-Franciaországban feltünő dualista alapállású eretneknek kikiáltott vallási mozgalom tagjait. Nevüket maguk a görög katharosz, vagyis tisztultak szóból eredeztetik.

8 Maximilien François Marie Isidore de Robespierre (Arras, Franciaország, 1758. május 6. - Párizs, Franciaország, 1794. július 28.) francia ügyvéd, politikus, forradalmár, a jakobinus diktatúra vezéralakja.

9 David C. Rapoport (1929-) a University of California professzora. Kutatási területének fókuszában a politikai eröszak és a terrorizmus áll.
} 
álló jogszabálytervezet először használta hivatalosan a terrorizmus kifejezést. Ezt követte az 1931-ben Franciaországban, majd 1934-ben Spanyolországban napirendre tüzött, a terrorizmus üldözésére vonatkozó törvénytervezet. A horvát usztasák által 1934-ben I. Sándor jugoszláv király ellen Marseilles-ben elkövetett merénylet utáni döbbenetet és felháborodást követően Európában megfogalmazódott egy nemzetközi egyezmény megkötésének szükségszerüsége a terrorizmus üldözésének vonatkozásában.

Természetesen a terrorizmus és a terrorcselekmények elleni hatékony fellépést nem csak az európai merényletek és szervezkedések sürgették. A világ más pontjain is kialakult olyan politikai helyzet, mely az indulatok ilyen irányú elfajulásához vezetett, és a szemben álló felek nem a békés párbeszédet szorgalmazták.

A 20. századi terrorizmus komolyabb megjelenése a Közel-Kelethez köthető, ahol már az előző századforduló időszakában súlyos szembenállás alakult ki az évszázadok óta ott élő palesztinok és az Európából Palesztinába kivándorolt zsidók között. Az Izrael néven létrejött zsidó állam 1948. május 14-i megalakulását követően a helyzet nem javult, sőt súlyosbodott. A zsidó-palesztin viszony és a környező arab államok ellenséges fellépése azt eredményezte, hogy a szomszédos országok azonnal megtámadták Izraelt, amely azonban képes volt megvédeni magát. Ettől kezdve a palesztinok és az arabok egymás után alakították terrorszervezeteiket a zsidók és a zsidó állam ellen.

1970-ben jött létre a Fekete Szeptember elnevezésű szélsőséges fegyveres csoport, mely leghíresebb akcióját 1972-ben hajtotta végre a müncheni olimpián, amikor tagjai tizenegy izraeli sportolót gyilkoltak meg. Ez a terrorcselekmény mérföldkővé vált a terrorelhárítás történetében is, hiszen ettől az eseménytől datálható több terrorelhárító szolgálat megalakítása a rendfenntartó erök kötelékében. Ez az esemény megalapozta, hogy a különleges müveleti erők feladatrendszerében egyre nagyobb szerepet kap a terrorelhárítás és az antiterror, valamint az ilyen feladatokra történő naprakész felkészülés követelménye. 1975-ben palesztin terroristák ismét nemzetközi porondra léptek, amikor Bécsben OPEC-tagállamok ${ }^{10}$ minisztereit rabolták el. Ez rávilágított arra, hogy innentöl a Közel-Keleten kívüli célpontok támadásával nem csak esetlegesen kell számolni.

A tragikus események rámutattak arra, hogy a terrorizmus immár a szélesebb nemzetközi szintre lépett, és ez a terrorizmus bárhol, bármikor lecsaphat, továbbá módszerei kíméletlenek lesznek. Számos szervezet módszerei között, a nagyobb figyelemfelkeltés érdekében, megjelent a túszejtés és a légi jármüvek eltérítése.

A terrorizmus fejlődésének az 1970-es évek közepéig történő áttekintésében említést kell tennünk azokról a csoportokról is, melyek valamilyen szeparatista célból alakultak és folytattak harcot adott régiók elszakadásáért. Ezek a szervezetek aktív müködésük idején komoly ismertségre tettek szert, a nemzetközi és a számukra hazai politika alakulása azonban napjainkra csökkentette aktivitásukat. Ezek közül a legrégebbi talán az Ír Köztársasági Hadsereg (Irish Republican Army - IRA), amely 1919-ben jött létre azzal a céllal, hogy a brit koronától független, önálló Írországot megteremtse. Hasonló céllal, a Spanyolországtól történő elszakadás szándékával alakították meg a baszkok 1959-ben Baszkföld és Szabadság (Euskadi Ta Askatasuna - ETA) elnevezésü szervezetüket, hogy csak a legismertebbeket említsük.

\footnotetext{
${ }^{10}$ Organization of the Petroleum Exporting Countries - Kőolaj-exportáló Országok Szervezete. 1960-ban Bagdadban alakult nemzetközi szervezet, amelynek elsődleges célja, hogy összehangolja tagországai kőolaj-kitermeléssel kapcsolatos politikáját.
} 
Mindezek mellett meg kell említenünk a viszonylag nagy számmal szerveződött baloldali, anarchista csoportokat is, mint például az 1967-ben alakult német Vörös Hadsereg Frakció (Rote Armee Fraktion), az 1970-ben létrehozott olasz Vörös Brigádok (Brigate Rosse) csoport, valamint az 1975-ben létrejött görög November 17 elnevezésü forradalmi szervezet. Természetesen a szélsőségesek a politikai jobboldalon is létrehoztak hasonló szervezeteket.

Az értékelt korszak terrorizmusának főbb jellemzői:

1. Céljai szerint: demonstratív, erőszakos cselekmények elkövetésével általános félelem keltése a célterület lakosságának minél szélesebb köreiben, ezáltal aláásni egy társadalom, egy ország stabilitását, nyomást gyakorolni annak vezetésére, hogy a terroristák akarata teljesüljön.

2. A megjelenés színtere szerint: az 1970-es évek közepére a terrorizmus a lokális és a regionális szintről továbblépett, és már szélesebb nemzetközi téren is komoly tényezővé vált, céljai eléréséhez igyekezett minél szélesebb nyilvánosságot teremteni.

3. Módszerei szerint: elsősorban fegyveres támadások, robbantások, öngyilkos merényletek, politikai gyilkosságok, emberrablás, túszejtés (több esetben tömegközlekedési eszközök eltérítésével).

4. Ideológiái szerint: a politikai ideológiák széles skálája mellett, jelentős mennyiségben és jelentős erőt képviselnek a szélsőséges vallási alapok, melyek sok esetben nemzeti, etnikai vonatkozásúak is.

5. Szervezetük jellemzői szerint: kialakulnak a jól szervezett, hierarchikus csoportok, szervezetek, melyek közös jellemzője a konspiráció és a szélesedő kapcsolatrendszer (nem egy esetben állami támogatással, háttérbázissal).

6. A terrorizmus már osztályokba sorolható: államilag nem támogatott, államilag támogatott, illetve rezsimhez köthetö. ${ }^{11}$

7. Az 1970-es évekre a terrorista szervezetek részéről megfigyelhető volt egyfajta törekvés az erőszak balanszírozására, miszerint a kevés erőszak nem alkalmas a figyelem felkeltésére, a túlzott viszont ellenérzést válthat ki irányukba, így kontraproduktívvá válhat a kitüzött cél elérése szempontjából. Ez a terrorista magatartás egyfajta kiszámítható, racionális viselkedést eredményezett. Ebben az időszakban a lassú, „történelmi” fejlödés volt jellemző; bár a terrorista szervezetek vezetői és tagjai részéről a tervezés, szervezés és végrehajtás, tehát az eredményes müködés vonatkozásában számos elképzelés merült fel, a megvalósítás - a lehetőségeik korlátozottsága miatt - váratott magára.

8. Kialakul a ,terrorista vagy gerilla, esetleg szabadságharcos? "12 dilemmakör. Az 1960as évekre a terrorista megnevezésnek meglehetősen negatív értelmezése lett, így azok a csoportok, szervezetek, amelyek például nemzeti felszabadítóként határozták meg önmagukat, vagy annak voltak tekinthetők - akár valamely nagyhatalmi törekvés ellenében -, alapvetően gerillaként, szabadságharcosként tekintettek önmagukra, semmint terroristaként. Mint ismeretes, a gerilla-hadikultúra mint irreguláris hadviselés a hadikultúrák részét képezi. ${ }^{13}$ De a gerilla-hadviselés eszköztárában terrorista módszerek is szerepelhetnek, melyeket nagy hatékonysággal alkalmaztak és alkalmaznak az erôteljesebb nyomás gyakorlására erősebb ellenfeleikkel szemben, ennek ellenére - megítélésem szerint - a két fogalom markánsan külön kezelendö.

\footnotetext{
${ }^{11}$ Kis-Benedek József: Dzsihadizmus, radikalizmus, terrorizmus. Zrínyi Kiadó, Budapest, 2016, 150.

${ }^{12}$ Lásd Kiss: i. m.

${ }^{13}$ Bővebben lásd Ágh Attila: Konfliktusok, háborúk. Zrínyi Kiadó, Budapest, 1989.
} 
Összességében megállapítható, hogy a terror és a terrorizmus egy több évezredes múltra visszatekintő jelenség, mely hosszú történelmi fejlődése során egyre szélesebb spektrumon mutatta meg pusztító arcát és vitathatatlan hatékonyságát az általános félelemkeltésben.

Az értékelt korszak végére elengedhetetlenül szükségessé vált a terrorizmus egyértelmü és egységes definiálása - amit nyilván itt különböző kategóriák indokoltak -, ami alapfeltétele annak, hogy meghatározhassuk, hogy mi, illetve ki ellen kell harcolni. Megítélésem szerint ennek egy nagy akadálya volt: a hidegháborús szembenállás, mivel a politikai, ideológiai szembenállás növelte a különbséget az egyes államok terrorról, terrorizmusról, de legföképpen egy adott terrorszervezet minősítéséröl alkotott állásfoglalásai között.

Ebben az időszakban - de ez sajnos napjainkig igaz - számos terrorszervezetnek és tagjainak biztosítottak hadmüveleti és kiképzési hátteret olyan államok, amelyek egyrészt „megértették”, de legalábbis „nem ítélték el” egyes szervezetek törekvéseit és módszereit, másrészt a támogatott terrorista szervezetek az ellenérdekelt országok területén készültek terrorcselekményeket elkövetni, amelyek eredménye kétségtelenül ,jól jöhetett” a támogatóik részére is. Ezek a kapcsolatok ezért jellemzően titokban, látens módon, a politikai színfalak mögött alakultak, de a terrorizmus módszereit, eszközeit a legtöbb állam nyilvánosan, manifeszt módon elítélte és elítéli a mai napig.

\section{TERRORIZMUS A 70-ES ÉVEK KÖZEPÉTŐL AZ EZREDFORDULÓIG}

Az 1970-es évek végére megjelent egy új terrorista generáció, melyet a korszak világpolitikai eseményei is erőteljesen alakítottak és befolyásoltak, valamint egyre inkább előtérbe került az iszlám terrorizmus, annak is az újabb vonulatai.

Az iráni iszlám forradalom során, 1979-ben Homeini ajatollah vallásos követői elfoglalták az Amerikai Egyesült Államok teheráni nagykövetségét, és ezzel egy 444 napos túszdráma bontakozott ki, melynek oka Washington folyamatos segítségnyújtása az elüzött iráni sah részére. Ez az esemény egyfajta mérföldkő volt azon az úton, amelynek nyomán Irán rövidesen világszerte a szélsőséges iszlám egyik fő támogatója lett. De mérföldkőnek tekinthető abban a tekintetben is, hogy az Amerikai Egyesült Államok és állampolgárai még nem igazán tudtak mit kezdeni az iszlám terrorizmus ilyenfajta új hullámával. Ezt a feltevést csak erősítette az 1980. április 24-25-én sikertelenül végrehajtott Saskarom (Operation Eagle Claw) hadmüvelet.

Ugyancsak elmondható erről az időszakról, hogy a nagyhatalmak politikai döntéshozói saját céljaik érdekében továbbra is, de már erőteljesebben próbálták kihasználni a szélsőséges militánsok erejét és müködését. Kiváló példa erre az amerikaiak által nyújtott támogatás az iszlám militánsok szovjetek elleni harcához az afganisztáni háború során.

A szovjetek afganisztáni háborúja és veresége ebben az időszakban kétségtelenül hozzájárult az al-Kaida megerösödéséhez, mivel a szervezet alapját lényegében a mudzsahed harcosok képezték, kiegészülve külföldi önkéntesekkel. A harcedzett, általuk erkölcstelennek tartott világtól elfordult „Isten harcosai”, a muszlim földek fegyveres védelméért indított dzsihádban részt vevő harcosok közül a szélsőségesek ekkor fordultak Oszama bin Laden felé, és személyében megtalálták új vezetőjüket, aki az iszlám legnagyobb ellenségét a szaúd-arábiai vahabita rezsimben és támogatójában, az Amerikai Egyesült Államokban látta megtestesülni.

A ,szent harcosok” korábbi támogatóik ellen fordulva az al-Kaidában gondolták annak a harcnak a lehetőségét, amellyel kifejezhetik tiltakozásukat Washington közel-keleti politikája ellen, és támogatásukról biztosították a Palesztina felszabadítására irányuló 
törekvéseket, valamint iszlám államok létrehozását világszerte. Ennek eredményeként az al-Kaida és más dzsihadista szervezetek már egyértelmüen szent háborút indítottak a „Nagy Sátán”, az Amerikai Egyesült Államok ellen.

Ezt követően, az 1990-es években gyakorivá váltak az amerikai érdekeltségek elleni terrorista akciók, melyek egyik jelentős eseménye volt a Világkereskedelmi Központ ellen 1993-ban intézett támadás. Innentől Bin Laden is egyértelműen az amerikai titkosszolgálatok fókuszában állt, de a folyamat folytatódott, és 1998-ra az al-Kaida vezetője már egy általa kiadott fatvában ${ }^{14}$ jogosnak minősítette az akciókat, és nyíltan buzdította híveit az amerikai érdekeltségek elleni támadásokra a világ minden részén.

Az ezredfordulóra az Amerikai Egyesült Államok több súlyos merényletet szenvedett el: 1998 nyarán a kenyai és a tanzániai nagykövetségeit érte támadás, majd 2000 októberében az Ádeni-öbölben haditengerészetének egyik rombolója, a USS Cole ellen követtek el öngyilkos akciót, hogy csupán a legnagyobbakat említsük.

Egyértelmü tendenciává vált, hogy a terrorizmus természete ezekben az években egyre pusztítóbb és agresszívabb lett. Szervezetei határokon átívelőkké váltak, és a korábbi időszakokhoz képest jóval kiterjedtebb nemzetközi szállítási és kommunikációs csatornákat használnak.

Az 1990-es évekre a terrorizmus igazodott a változó világhoz, és új, minden eddiginél veszélyesebb arcát mutatva lépett színre. Benjamin Netanjahu ${ }^{15}$ Harc a terrorizmus ellen című művének előszavában így ír erről az ,átrendeződésről”: , A terrorizmus bosszúszomjasan tért vissza. Miután az 1980-as években nemzetközi szinten és a legtöbb nyugati országban sikerült visszaszoritani, most kegyetlen, félelmetes alakot öltve tért vissza újra. Az Egyesült Államokban a manhattani Világkereskedelmi Központ, valamint az Oklahoma Cityben található kormányzati központ elleni robbantások érzékeltették az amerikaiakkal, hogy a terrorizmus már a föutcán is képes lecsapni." 16

A későbbi izraeli miniszterelnök könyvében megfogalmazza a különbséget is, ami a múlt és a jelen terrorizmusa között érzékelhető. „Az új terrorhullámban fellelhető modus operandi egyértelmüen eltér a világot a hatvanas évek óta több mint két évtizeden át nyomasztó terrorizmustól. Az új keletü terrorizmus már nem nagyon »dicsekedhet « túszejtéssel, s a gépeltéritések gyakorlatilag teljesen megszüntek. A ma terroristája a célpont felrobbantására specializálódott, s erre jó oka van: az 1980-as években a túszejtőkre, a géprablókra és támogatóikra kimért büntetések minden szempontból költséges ügyletté változtatták a terrorizmus nyiltabb formáit. Az új keletü terrorizmusban részt vevö új és nem is annyira új erök a büntetés elkerülése érdekében még a sötétséget kedvelö elödeiknél is sokkal mélyebben húzódnak meg az árnyékban." 17

Az 1995-ben kiadott szakirodalom utal arra, hogy a terroristák jól ismerik potenciális ellenfeleiket, és megfelelö koncepció mentén fel is készülnek belölük, ezért ezt az elhárítás oldaláról is figyelembe kell venni. „[a terroristák, terrorista szervezetek] Nagyon jól ismerik ugyanis a Nyugatot, és kidolgozták azokat a stratégiákat, amelyek segítségével hasznot

\footnotetext{
${ }^{14}$ Fatva vagy fetva az iszlám vallásban vallásjogi döntést jelent, amelyet egy arra képzett személy hoz olyan esetekben, amikor egy hitelméleti kérdésre nincs válasz a Koránban vagy a muszlim tudósok közmegegyezésében.

15 Benjamin Netanjahu (Tel-Aviv, Izrael, 1949. október 21. -) izraeli politikus, miniszterelnök, az izraeli hadsereg különleges eröinek egykori tagja.

${ }^{16}$ Benjamin Netanjahu: Harc a terrorizmus ellen - Hogyan lehet legyőzni a nemzetközi terrorizmust. Alexandra Kiadó, Budapest, 1995, 15.

17 Uo.
} 
húzhatnak gyenge pontjaiból. A terrorizmus elleni hatékony fellépés szükségszerüen megköveteli azokat a belpolitikai és nemzetközi politikai lépéseket, amelyek visszatarthatják a terrorizmus térnyerését és kiküszöbölhetik az annak táptalajt adó eröfeszitéseket."18

Már nem kérdéses, hogy a 21. század egyik legnagyobb biztonsági fenyegetése a nemzetközi terrorizmus és az ahhoz kapcsolódó cselekmények lesznek.

Az értékelt korszak terrorizmusának jellemzői:

1. Céljaik szerint: továbbra is demonstratív eröszakos cselekmények elkövetésével általános félelem keltése a célterület vagy -térség lakosságának, közösségeinek minél szélesebb köreiben, ezáltal aláásni egy társadalom, egy ország stabilitását. A vizsgált időszakban azonban megfigyelhető volt, hogy a legjelentősebb terrorszervezetek már komoly stratégiai pozíciókat voltak képesek elfoglalni, ezzel együtt jelentős fenyegető tényezővé válni mind politikai, mind gazdasági, valamint társadalmi és katonai vonatkozásban is. Folyamatosan ennek a pozíciónak az erősítésére törekedtek, és ellenségeik elpusztítása mellett nyílt háborút hirdettek.

2. A megjelenés szintere szerint: a terrorizmus lokális, regionális és nemzetközi szinten egyaránt továbbra is jelen volt. De a globalizáció hatása, a tér és idő jellemzői, a villámgyors hatásmechanizmusok miatt már olyan nemzetközi fenyegetéssé vált, amellyel egyértelmüen globális szinten is számolni kellett.

3. Módszereik szerint: fegyveres támadások, robbantások, öngyilkos merényletek, politikai gyilkosságok, emberrablás, túszejtés - több esetben tömegközlekedési eszközök eltérítésével. Módszereik egyre kíméletlenebbek és pusztítóbbak lettek.

4. Ideológiáik szerint: a politikai ideológiák széles skálája mellett felerősödtek a szélsőséges vallási alapok (melyek nemzeti, etnikai megerösítést is nyertek).

5. Szervezetük jellemzői szerint: kialakultak a jól szervezett, hierarchikus csoportok, szervezetek, melyek közös jellemzője a konspiráció és a kiterjedt, határokon átívelő kapcsolatrendszer volt, továbbra is sok esetben állami támogatással és háttérbázissal.

6. Az 1970-es években jellemző erőszak-balanszírozás eltünt, a jelentős terrorista szervezeteknek ez már nem volt érdekük. Ezt felváltották magasabb intenzitású módszerek, amelyek alkalmasak voltak a figyelem széles körü felkeltésére és az erőteljesebb nyomásgyakorlásra. Megítélésem szerint a terroristák részéről ezek a cselekvési módozatok is hordoztak egyfajta kiszámíthatóságot, racionalitást, ez azonban már másként értendő, mint korábban. Ebben az időszakban jellemzővé vált az átrendeződés, és a terrorista szervezetek módszerei, eszközei tekintetében is jelentősebb változások következtek be, ami a szervezetek és a támadások hatékonyságát növelte. Mondhatni, hogy ez volt a nagy átmenet időszaka.

Összességében megállapítható, hogy a hidegháború utolsó évtizede, majd a kétpólusú világrend megszünését követő unipoláris világrend évtizede, utóbb pedig a multipolárissá vált világ politikai eseményei átalakulást eredményeztek a terrorizmus világában is. Véleményem szerint ebben az időszakban már szárba szökkent egy, a teljes világot behálózó, globális és szélsőséges ideológiákon nyugvó terrorizmus, mely a 21. században már határokon és kontinenseken átívelő fenyegetést jelent. 


\section{A 21. SZÁZAD TERRORIZMUSA}

A harmadik évezred első évtizedeinek nemzeteken átívelő biztonsági kihívásai nem minden tekintetben új keletűek, inkább tekinthetők egy folyamat újabb epizódjának. Megítélésem szerint érzékelhető, hogy a terrorizmus is része ennek a folyamatnak és lényeges negatív „karaktere” az újabb fejezetnek is. Napjaink terrorszervezetei nagy szervezettséget mutatnak, jelentős anyagi hátteret és magas technikai bázist tudhatnak maguk mögött, így már lényegesen nagyobb szabású akciókat képesek végrehajtani. Müködésüket tekintve a szervezetek még inkább konspiráltak, de elrettentő támadásaik a lehető legnagyobb figyelmet vonják magukra.

Nagyon sokszor emlegetett megállapítás, de mindenképpen igaz, hogy az Amerikai Egyesült Államokban 2001. szeptember 11-én végrehajtott terrortámadások - melyek a történelem legnagyobb méretü terrorakciója keretében történtek - mérföldkövet jelentettek a terrorizmus arculatváltásában. A terrorizmus egyértelmüen megüzente, hogy sehol senki nincs biztonságban, hiszen a világ vezető nagyhatalmát a saját földjén támadták meg egy nagyszabású terrorista müvelet során. Ez a cselekmény azonnal világméretű hatásokat eredményezett, kezdve az Amerikai Egyesült Államok katonai müveleteitől a különböző magas szintü biztonsági intézkedések (például a repülésbiztonság terén) bevezetéséig.

A szeptember 11-i terrortámadást követően az emberek figyelme az új vallási terrorizmus irányába fordult, amelyet az al-Kaida franchise-jelenség csak fokozott. Egyesek fenyegető rémet, mások egy új világrend letéteményesét látják ebben, mivel a globalizáció negatív következménye a társadalmi rétegek között kialakuló és mélyülő egyenlőtlenség. Ennek további eredménye, hogy a nyugati világ a maga értékrendjével egyfajta ellenségképet jelent az elszegényedett, sokszor a napi létükért küszködő tömegek szemében. Ezek a manipulálható tömegek a sokszor az összeomlás szélén álló államokban kiváló bázist és utánpótlási lehetőséget jelentenek a terrorista szervezetek számára.

Ezzel együtt napjaink másik biztonsági kihívása, a migráció összefüggése is felmerül, mivel egyfelől a bevándorló tömegekkel együtt nagyszámú olyan személy érkezhet ellenőrizetlenül, akik terrorszervezetek tagjai, egykori harcosai, illetve szimpatizánsai. Másfelől számos országban alakulnak ki nehezen ellenőrizhető kolóniák (no-go zónák), amelyek szintén kiváló hátteret nyújtanak az adott országok vagy régiók területén a terrorszervezetek hatékonyságához, mivel ott komoly háttérbázisokat hozhatnak létre. Ezek a folyamatok több hivatalos állásfoglalás szerint az elkövetkezendő években sem szünnek meg, így a terrorizmus ellen elsöprő győzelem nem várható. Az iszlám a szélsőséges politikai irányzatával a Közel-Keleten túl Európára is jelentős hatást gyakorolt és gyakorol, amihez az említett migrációs folyamatok kedvező hátteret biztosítanak.

Megállapítható, hogy a legjelentősebb, ezáltal a legnagyobb biztonsági fenyegetést jelentő terrorszervezetek nemcsak lokálisan, hanem határokon átnyúló, globális szinten fejtik ki tevékenységüket; csoportjaik, sejtjeik és tagjaik jelen vannak háborús területeken, különböző konfliktuszónákban csakúgy, mint a mindennapi békés életet élő városokban. Több terrorszervezet látványosan „kinőtte magát”, és már az élőerő, valamint fegyverzeti, technikai felszereltség, de akár a kiképzés tekintetében is jelentős erőt képvisel, ami évtizedekkel ezelőtt még nem volt jellemző.

Kijelenthető az is, hogy a terrorcselekmények végrehajtását szerteágazó és részletes információgyüjtés és tervezés előzi meg, valamint az előkészületek fázisa is komoly hangsúlyt kap. Igen csekély annak a valószínüsége, hogy valaki egyik napról a másikra, egyszerủen, minden átmenet nélkül hajtson végre egy merényletet. Ez természetesen nem elképzelhe- 
tetlen, de nem ebben a kategóriában. A kijelölt célpontok megtámadása és a meghatározott eredmény sikeres elérése érdekében a terroristáknak ki kell választaniuk a megfelelö módszereket (taktikai eljárásokat) és a szükséges eszközöket, majd felkészülni a feladat végrehajtására. Ez a folyamat, vagyis maga a támadás ciklusa természetesen a múltban is létezett, ebben változás aligha észlelhető. A támadások során alkalmazott módszerekben, eljárásokban viszont vannak változások.

Az általános vélekedés szerint a terrorcselekmények törvényszerü velejárói a terrorista csoportok által végrehajtott robbantások, löfegyverekkel, különböző hidegfegyverekkel, szükségeszközökkel végrehajtott erőszakos támadások. Szintén törvényszerü velejáróinak tekintik a túszejtéseket, a jelentős anyagi javak vagy az állam müködése, a lakosság ellátása szempontjából kiemelt fontosságú, illetve kritikus infrastruktúra részét képező létesítmények elfoglalását, ellenőrzését, valamint azokat a különböző követeléseket, melyeknek a teljesítésétől teszik függővé a túszok szabadon bocsátását, a létesítmények sértetlenségét.

A korábbi évtizedekben jellemző csoportos elkövetés mellett egyre nagyobb számban fordulnak elő olyan elkövetők, akik saját országon, térségen belül „építik fel” magukat és követik el támadásaikat, különböző erőszakos cselekményeiket. Ezt a jelenséget a szakirodalom „hazai terrorizmus” (domestic terrorism) kifejezéssel illeti. Ez esetben a helyszín, a célpontok és az elkövetők is jellemzően ugyanabból az országból (térségből) származnak, vagy ott találhatók, oda köthetők. Az elmúlt évtized néhány ilyen jellegü cselekménye: Breivik által elkövetett tömegmészárlás a norvég Utoya szigetén (2011), az amerikai Orlandóban egy melegbár ellen elkövetett támadás (2016), az új-zélandi Christchurchben két mecset ellen elkövetett merénylet (2019).

A szakirodalomban - ezen belül - megkülönböztetnek úgynevezett „,bennszülött” terroristákat, akik az esetek nagy részében valamely terrorszervezethez, terroristacsoporthoz tartoznak, valamint olyan egyéni elkövetőket, „magányos farkasokat”, akiknek szervezeti hovatartozása nem bizonyítható, vagy ilyen kapcsolata nem is létezik.

Ezek a jellemzők nagyban megnehezítik a felderítést, komoly nehézséget gördítenek a radikális események megelőzésének útjába, legtöbbször már csak a tragikus eseményekkel és azok következményeivel szembesülünk. ${ }^{19}$

A túszejtések továbbra is jellemzőek, viszont nagy számban megjelentek a túszejtések olyan esetei, amikor már nem egy későbbi tárgyalási alapot szolgálnak, hanem időhúzást, egy nagyobb terrorista müvelet részeként egyfajta játszmát alapoznak meg, vagy a túsz(ok) későbbi, demonstratív kivégzését készítik elő. Jellemzővé vált, hogy a terroristák már nem akarják túszaikat élve szabadon bocsátani, vagyis már nem akarnak párbeszédet, ehelyett inkább további brutális tetteikkel akarják demonstrálni céljaik iránti elszántságukat.

Egyre nagyobb számban jelennek meg a támadások során az aktívlövész-szituációk, melyek során egy vagy több személy véletlenszerüen vagy szisztematikusan kiválasztott élö célpontokat támad meg egyértelmủ gyilkolási szándékkal. Magatartásukkal cselekményük során határozottan és töretlenül demonstrálják azt a szándékukat, hogy a legfontosabb céljuk a tömegmészárlás, a lehető legnagyobb pusztítás elérése a támadás helyszínén tartózkodók körében. A korábban említett támadások ebbe a kategóriába tartoznak, de közéjük sorolhatóak az iszlám szélsőségesek által 2015. november 13-án este Párizsban elkövetett terrortámadások is.

${ }^{19}$ Kis-Benedek: i. m. 189. 
Cselekményük során lőfegyvereket, robbanóeszközöket és hidegfegyvereket egyaránt alkalmaznak. Ezekre a támadásokra jellemzö, hogy az elkövetők mindaddig folytatják a támadást, amíg harcképtelenné nem válnak, vagyis öngyilkos támadásoknak is tekinthetők az ilyen akciók, melyeket gyakran öngyilkos robbantásokkal is összekötnek.

Elöfordul különböző, általában nagy tömegü jármüveknek a támadás eszközeként (lényegében fegyverként) történő alkalmazása elsősorban forgalmas helyeken, tömegrendezvényeken, amikor az aktívlövész-szituációhoz hasonlóan a jármü vezetője egyértelmü és folyamatos ölési szándékkal támad nagyszámú személyre. A cél itt is az elérhető legnagyobb pusztítás, és természetesen ez a módszer is kombinálható más módszerekkel, például lőfegyver, robbanóanyag alkalmazásával.

Végül - de természetesen nem utolsósorban - megemlítem az öngyilkos robbantásokat is, de azonnal hozzá is füzöm, hogy nem a módszer újdonsága, hanem az alkalmazások jelenlegi, világszerte növekvő tendenciái miatt. Ennek az olcsó, viszonylag egyszerü technikát alkalmazó eljárásnak a demoralizáló hatása vitathatatlanul óriási a tényleges, fizikai pusztításon túl. A módszer napjainkban leginkább a vallási indíttatású terrorizmushoz köthető, ahol a merénylet sikeres végrehajtása egyfajta Isten dicsőségére végrehajtott mártírhalál az elkövető számára.

A fenti módszerek további közös jellemzői:

- meglepetésszerü támadások, ezért legtöbbször viszonylag könnyen elérhető célpontok ellen hajtják végre;

- időben viszonylag gyors lefolyású események (a túszejtések esetében általában a személyek túszul ejtésének idejéig, majd a legtöbb esetben kialakult ún. „,barikádhelyzetben" ez már időben lényegesen elhúzódhat);

- a támadások a célszemélyek, célpontok teljes megsemmisítésére, illetve a lehető legnagyobb kár okozására törekszenek, a lehető legrövidebb időn belül;

- a módszerek a nagyobb hatás érdekében egymással kombinálva is alkalmazhatók;

- demonstratív végrehajtás;

- a fenti terrorcselekmények közvetlen hatásaként a helyszíneken azonnal jelentős mértékü pusztítás tapasztalható, az eredmény jellemzően több halott és sebesült személy, valamint az anyagi javakban bekövetkezett rombolás, károkozás.

A terrorizmus fejlödésének, történetének áttekintését követően kijelenthető, hogy az jelenleg folyamatos, dinamikus és az ellene hozott intézkedésekre reagáló rugalmas változásban van. Véleményem szerint ez értendő a szervezeti felépítésekre, hálózatok kialakítására, müködtetésére, valamint az alkalmazott módszerekre és eszköztárakra.

A gyakorlatban látható, érzékelhető, hogy az adott időszakban bevezetett hatósági intézkedések milyen mértékben gyakoroltak hatást a terrorcselekmények végrehajtásának módszereire, eszközeire. Például a 9/11 után bevezetett szigorú repülésbiztonsági szabályok, ellenőrzések, vagy jármüvel elkövetett (vehicle-ramming) támadások elhárítására, csökkentésére a tömegrendezvények helyszínein alkalmazott fizikai akadályok elhelyezése, de a jármüvédelem különböző technikai megoldásai, fejlesztései is hatást gyakorolhatnak.

A fejezet végén rövid áttekintésként egy táblázatban foglalom össze a terrorizmus fejlödését a fenti szakaszok vonatkozásában. Megjegyzendő, hogy az időszakok közötti átmeneteket is figyelembe véve természetesen nem választhatóak el ilyen élesen az egyes periódusok jellemzői, de jól látható a változás folyamata, ami a terrorizmust napjainkra a globális fenyegetések közé emeli. 
1. táblázat A terrorizmus fejlödése a tárgyalt szakaszok vonatkozásában (Szerkesztette a szerzö)

\begin{tabular}{|c|c|c|c|}
\hline TERRORIZMUS & $\begin{array}{l}\text { a 19. század második } \\
\text { felétől 1970-ig }\end{array}$ & 1970-től 2000-ig & 2000-től napjainkig \\
\hline Céljaik szerint & \multicolumn{3}{|c|}{$\begin{array}{l}\text { demonstratív, erőszakos cselekmények elkövetésével általános félelem keltése } \\
\text { a célterület vagy -térség lakosságának, közösségeinek minél szélesebb köreiben, } \\
\text { ezáltal aláásva egy adott társadalom, egy ország, illetve politikai rendszer } \\
\text { stabilitását POLITIKAI, VALLÁSI, IDEOLÓGIAI CÉLOK elérése érdekében }\end{array}$} \\
\hline $\begin{array}{l}\text { Megjelenés } \\
\text { színtere }\end{array}$ & $\begin{array}{l}\text { lokális, } \\
\text { regionális }\end{array}$ & nemzetközi & $\begin{array}{l}\text { nemzetközi, } \\
\text { globális }\end{array}$ \\
\hline $\begin{array}{l}\text { Jellemző } \\
\text { módszereik }\end{array}$ & $\begin{array}{l}\text { - politikai gyilkosságok; } \\
\text { - robbantások; } \\
\text { - öngyilkos merényletek; } \\
\text { - emberrablás, túszejtés } \\
\text { (közlekedési eszközök } \\
\text { eltérítésével); } \\
\text { - szimbolikus célpontok } \\
\text { támadása }\end{array}$ & $\begin{array}{l}\text { - politikai gyilkosságok, } \\
\text { merényletek; } \\
\text { - öngyilkos robbantások; } \\
\text { - túszejtés (közlekedési } \\
\text { eszközök hatalomba } \\
\text { kerítésével); } \\
\text { - emberrablás; } \\
\text { - szimbolikus célpontok } \\
\text { támadása }\end{array}$ & $\begin{array}{l}\text { - öngyilkos robbantások; } \\
\text { - aktívlövész-szituációk; } \\
\text { - jármúvel elkövetett } \\
\text { támadások; } \\
\text { - túszejtés (közlekedési } \\
\text { eszközök hatalomba } \\
\text { kerítésével) - de jellemzően } \\
\text { a túszok demonstratív } \\
\text { kivégzése a cél; } \\
\text { - szimbolikus célpontok } \\
\text { támadása; } \\
\text { - konkrét harccselekmények } \\
\text { végrehajtása (pl. az Iszlám } \\
\text { Állam tevékenysége) }\end{array}$ \\
\hline Szervezettség & $\begin{array}{l}\text { hierarchikus csoportok, } \\
\text { szervezetek }\end{array}$ & $\begin{array}{l}\text { - a szervezetek } \\
\text { kiterjedtebb, } \\
\text { nemzetközi szintű } \\
\text { müködése; } \\
\text { - összefonódás, } \\
\text { kapcsolatok és aktív } \\
\text { részvétel egyéb } \\
\text { területeken } \\
\text { (pl. szervezett bünözés) }\end{array}$ & $\begin{array}{l}\text { - jól szervezett és irányított, } \\
\text { hálózatszerű, határokon } \\
\text { átnyúló szervezetek; } \\
\text { - „hazai terrorizmus” } \\
\text { (bennszülött terroristák, } \\
\text { magányos farkasok) }\end{array}$ \\
\hline Egyéb jellemzők & erőszak-balanszírozás & $\begin{array}{l}\text { növekvő pusztító } \\
\text { erőszak }\end{array}$ & $\begin{array}{l}\text { totális erőszak: } \\
\text { a terrorcselekmények során } \\
\text { az elérhető legnagyobb } \\
\text { pusztítás véghezvitele }\end{array}$ \\
\hline
\end{tabular}

\section{A HELYSZÍNI REAGÁLÓERŐK FELKÉSZÍTÉSÉNEK KÉRDÉSKÖRE}

A terrorizmus történetének és jellemzőinek áttekintését követően áttérek a reagálóerők szerepére és felkészítésének kérdéseire.

Az Európai Unió Tanácsának 2005. november 30-án Brüsszelben kiadott Terrorizmusellenes Stratégiája ${ }^{20}$ meghatározta, hogy az EU terrorizmusellenes stratégiája négy pilléren (megelőzés, védekezés, üldözés és reagálás) nyugvó rendszeren alapul és illeszkedik a stratégiai kötelezettségvállalásba:

${ }^{20}$ Az Európai Unió Terrorizmusellenes Stratégiája. Brüsszel, 2005. 11. 30., 3. https://data.consilium.europa.eu/ doc/document/ST\%2014469\%202005\%20REV\%204/hu/pdf (Letöltés időpontja: 2020. 12. 20.) 
- Megelözés: alapvető cél a terrorcselekmények, terrorjellegü büncselekmények elkövetéséhez vezető radikalizálódás megelőzése, különös tekintettel a terroristává válás prevenciójára, valamint a különböző terrorista célú médiatartalmakhoz történő hozzáférés kontrolljára.

- Védekezés: elsősorban a lakosság és a kritikus infrastruktúra védelme tartozik ide, ami egy igen tág területet és tevékenységi rendszert igyekszik lefedni (határvédelem, határellenőrzés, közlekedésbiztonság, kritikus infrastruktúra és a lakosság ellátása szempontjából kiemelt objektumok, ellátási láncok védelme stb.).

- Üldözés: legfőképpen a nemzetbiztonsági, rendvédelmi és igazságügyi hatóságok müködésében és együttmüködésében kell megvalósulnia, és a terroristák mozgásának és tevékenységének megakadályozására, finanszírozásuk elleni küzdelemre irányul.

- Reagálás: ez a pillér a terrortámadások következményeire tendál, az ezzel kapcsolatos reagálási képességet jelenti, melyet az alábbiakban részletesebben kifejtek.

Ez a négy terület 2020-ban kiegészítésre került az elörejelzés megfogalmazásával, mely valóban kritikus fontosságú és összefügg az összes többi területtel.

Jelen írásomban - mivel annak témájához szorosan kapcsolódik - csak a reagálást emelem ki, melyet a Stratégia így fogalmaz meg: „Az Unió felkészülése a terrortámadások következményeinek kezelésére és minimalizálására, képességeink javitásával a támadás utáni helyzet, a reagálás koordinációja és az áldozatok szükségletei kezelése terén." 21

A továbbiakban a fenti fogalmat tekintem irányadónak, amikor a reagálásban részt vevő erőket határozom meg, miszerint írásomban idesorolom azokat a szervezeteket, szolgálatokat, melyek állománya tevékenyen részt vesz a terrorcselekmények helyszínén történő intézkedésekben, így az állami fegyveres és rendfenntartó erőket (fegyveres erőket és rendvédelmi szerveket, illetve testületeket), a titkosszolgálatokat, a katasztrófaelhárításra kijelölt egységeket, szervezeteket, mentőszolgálatokat. Megítélésem szerint idesorolhatók a civil biztonsági szolgálatok is, amelyek jelenléte egy esetleges terrorcselekmény helyszínén egyértelműen lehetséges (például tömegrendezvények, bevásárlóközpontok stb.), így a tevékenységük szakszerüsége és gyorsasága, tehát ez irányú felkészültségük egyáltalán nem elhanyagolható.

A felsorolt szervezetek, testületek és szolgálatok - azzal együtt, hogy potenciálisan érintettek vagy érintettek lehetnek egy terrortámadás megelőzése, elhárítása vagy felszámolása során - a reagálásban természetesen nagymértékben eltérő feladatrendszerrel, kötelezettségekkel bírnak, jellemzően az alábbi sorrendben:

- állami fegyveres erök, rendvédelmi szervek, nemzetbiztonsági szolgálatok azon egységei, melyek fő feladata a terrorelhárítás, antiterror-müveletek végrehajtása (elsősorban terrorelhárító egységek, különleges műveleti erők állománya);

- állami fegyveres erők, rendvédelmi szervek, nemzetbiztonsági szolgálatok állományából azon szervezeti elemek, amelyek támogató tevékenységükkel érintettek vagy érintettek lehetnek a terrorelhárítás feladataiban;

- katasztrófák elhárítására, felszámolására létrehozott vagy kijelölt szervezetek, mentőszolgálatok állománya, melyek közremüködhetnek egy terrorcselekmény elhárításának vagy felszámolásának helyszínén, tevékenységükkel támogatják az élet- és vagyonmentést, a károk minimalizálását (elsősorban állami és önkormányzati tűzoltóság, katasztrófavédelmi egységek, mentőszolgálatok, valamint olyan egységek, szer- 


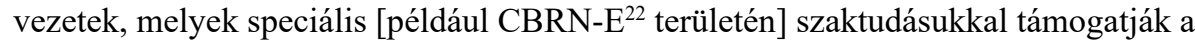
terrorcselekmények pusztító hatásainak elhárítását, csökkentését);

- civil biztonsági szolgálatok (elsősorban a kritikus infrastruktúra elemei, nagy látogatottságú, forgalmas épületek, intézmények védelmében, nagy tömegrendezvények biztosításában érintett biztonsági szolgálatok állománya).

Mint azt e tanulmány elején is megjegyeztem, ebben a láncolatban, illetve összefüggésrendszerben nagyon fontos szerepe van magának a lakosságnak, a társadalomnak is, mert biztonságtudatos, fegyelmezett magatartással jelentősen segíthetik a terrorcselekmények helyszínén reagáló erők munkáját.

Napjaink terrorcselekményeire jellemzö, hogy:

- meglepetésszerüek, gyors lefolyásúak;

- végrehajtásuk általában rendkívül dinamikus;

- rendkívül agresszívek;

- kiterjedt helyszíneken hajtják végre azokat.

Napjaink terrorcselekményeinek tervezése, szervezése és végrehajtása jellemzően jól szervezett és irányított, képzett csoportok és egyének konspirált együttmüködésével valósul meg, gyakran határokon átnyúlóan, a 21. század terrorizmusát jellemző hálózatalapon, ami jelentősen nehezíti a korai felismerést, így a megelözést is. Az egyéni elkövetők esetében a felderítés nehézsége hatványozottan igaz, amit a felkészülésnél mindenképpen és teljes mértékben figyelembe kell venni. Ezért az előrejelzés kiemelt jelentőséggel bír mind alapelvszinten, mind aktív, a gyakorlatban müködtetett rendszerként.

A terrorizmus elleni küzdelem, a terrorcselekmények megelőzése, megakadályozása vagy felszámolása sikerének érdekében az első és a legfontosabb a felkészítés területén, hogy a lehető legjobban ismerjük és értsük az ,ellenfelet” (például egy adott terrorista szervezetet). Ismerjük történetét, céljait, eszközeit, módszereit, felépítését, müködési rendjét, belső folyamatait, társadalmi rekrutációs bázisát és kapcsolatrendszerét, tagjainak főbb motívumait, jellemzőit stb.

Különösen a tervezés és a felkészülés szakaszában azonban tekintettel kell lenni arra a tényre is, hogy napjaink terrorizmusa, terrorista szervezetei a cselekmények előzetes elgondolásától a kivitelezésig rendkívül széles skálán és igen rugalmasan válogathatnak. Amilyen támadás elképzelhető és megvalósítható, valamint az adott terrorszervezet ehhez megfelelő anyagi-technikai háttérrel is rendelkezik, akkor az meg is valósulhat.

Tehát a tervezés, felkészülés fázisát át kell hatnia ennek az elvnek, ezért a reagálóerőknek is ugyanilyen határtalan fantáziával kell rendelkezniük a harc hatékony megvívása érdekében. Ez meghatározza a felkészülés tervezését, szervezését, folyamatát, valamint az ehhez szükséges eszközrendszert.

A reagálóerők terrorcselekmények helyszínein végrehajtandó feladatai az alábbi időbeli fázisok szerint különíthetők el:

- a terrorcselekmény bekövetkezése elött;

- a terrorcselekmény bekövetkezése közben, annak folyamatában;

- a terrorcselekmény felszámolását követő időszakban.

${ }^{22}$ Chemical, Biological, Radiological, Nuclear and Explosives - a vegyi, biológiai, radiológiai, nukleáris és robbanóanyagokat jelöli. 
Mint azt említettem, a terrorizmus elleni hatékony fellépés fontos részét képezi az elörejelzés, vagyis az előrejelző rendszerek kidolgozása és müködtetése. Az ilyen rendszereknek és a reagálóerőknek szoros kapcsolatban kell lenniük egymással, ezért a különböző érintett szervezetek, szolgálatok különböző eljárásrendjeit mindenképpen harmonizálni kell.

Az előrejelzés meghatároz egy veszélyeztetettségi fokot, de ettől függetlenül - tekintettel a terrorcselekmények végrehajtásának jellemző gyorsaságára és váratlanságára - szükséges a támadásokra történő reagálás idejét a lehető legrövidebbre csökkenteni. Ez az érintett szervek készenléti szolgálati és riasztási rendszerének optimális szervezésével és müködtetésével érhető el. A reagálás ideje tovább javítható speciális szakmai gyorscsoportok létrehozásával, amelyek fő feladatai az ilyen jellegü események helyszínén történő elsődleges intézkedések megtétele, információk begyüjtése és továbbítása.

Ugyancsak idetartozik a fegyveres rendfenntartó erők területi jelenléte, ami szükség esetén megerősíthető a fegyveres erők állományából. Napjainkban nem meglepő utcakép a közterületeken rendőri és katonai járörök, csoportok látványa, különösképpen a kritikus infrastruktúrák elemeinél, frekventált turisztikai látványosságoknál és tömegrendezvényeken.

Véleményem szerint az állandó közterületi jelenlét a gyors reakció szempontjából nagyon lényeges, viszont a jelentős mértékü, demonstratív ilyen jellegü tevékenység már nyomasztó lehet a lakosság és a turisták körében, amit figyelembe kell venni annak mértéke és alkalmazási elvei, körülményei meghatározásánál.

Az együttmüködés, a helyszínen dolgozó erők tevékenységének koordinálása miatt kiemelt jelentőségü egy olyan müveleti központ mielöbbi felállítása, ahol minden szerv és szolgálat képviselteti magát összekötőin keresztül, továbbá ahol az információáramlást segítő, hatékony, gyors és egyértelmű kommunikáció rendszere mielőbb kiépíthető. Lényeges a feladatok egyértelmü elosztása, meghatározása, valamint az egyes feladatok felelőseinek kijelölése.

A különleges műveleti erők és a terrorelhárító szolgálat vonatkozásában kiemelt jelentőséggel bír a vonatkozó taktikai eljárások (harceljárások) folyamatos felülvizsgálata, szükség esetén változtatása, valamint azok begyakorlása komplex rendszerben, tehát olyan módon, hogy már az együttmüködő további szolgálatok állományával összetett gyakorlatok keretében valós időben és térben, összehangoltan gyakorolja mindenki a feladatait.

Korábbi kiképzői tapasztalataim alapján állítom, hogy a realisztikus képzés keretében - az eredményesség érdekében - a potenciálisan előforduló változók teljes skáláját számba kell venni, és mindegyikre érdemes gyakorlatorientáltan felkészülni. Ezzel a módszerrel jelentősen növelhető a kommunikáció, az együttmüködés hatékonysága a résztvevők között, ami az eredményesség szempontjából egyértelműen kulcsfontosságú.

A terrortámadás helyszínén eluralkodó pánikhangulat - ami akár azonnal tömegeket mozgathat meg - jelentősen nehezítheti a helyzet stabilizálását, ezzel a veszteségek minimalizálását, valamint akadályozhatja a kiérkező rendfenntartó és mentőegységek gyors, hatékony müködését. Ez különösen igaz abban az esetben, amikor a kiérkező reagálóerők nem egy már lezárult, hanem egy még folyamatban lévő terrorcselekménnyel szembesülnek. Ilyenkor a fenyegetés megszüntetésére - a még aktív támadók lokalizálására és harcképtelenné tételére - irányuló elsődleges feladatok mellett lehetőség szerint meg kell kezdeni a sebesültek mentését, a további veszteségek lehetőségének csökkentését.

A helyszínre érkező rendfenntartó és a mentésben részt vevő egyéb egységek részéről elengedhetetlen a gyors helyzetfelismerés és a gyors döntéshozatal. Mindez egy olyan környezetben, ahol a szituációs éberségnek a lehető legmagasabb szinten kell müködnie, hiszen 
egy ilyen helyszín alapvetően és elsődlegesen veszélyes (ellenséges) területként kezelendö, mivel csak fokozatosan tudjuk teljes mértékben az ellenőrzésünk alá vonni.

A helyes és gyors helyzetfelismerés, döntéshozatal, maga a szituációs éberség is magas szintü szakmai felkészültséget igényel, ami magában foglalja a képzéseken tanult eljárásokat, eszközök ismeretét és szakszerü kezelését, továbbá a gyakorlati tapasztalatot, szakmai jártasságot. Kérdés persze, hogy rendfenntartó vagy mentőegység tagjaiként leszünk-e olyan pszichés állapotban, hogy a feladatainkat a szakmai utunk során tanultak, tapasztaltak alapján a leghatékonyabban tudjuk végrehajtani.

Megítélésem szerint a helyzetfelismeréssel, döntéshozatallal, szituációs éberséggel öszszefüggésében kiemelten fontos jelentősége lehet a lélektani felkészítésnek és felkészültségnek: annak, hogy a reagálóerők tagjai - a csoportmunka ellenére - egyénileg miként lesznek képesek uralni érzelmeiket egy terrorcselekmény vizuálisan is megrendítő, dinamikusan változó, veszélyes helyszínén és körülményei között. Ezért az ilyen irányú felkészítésnek mindhárom fent említett időszakban meghatározó szerepe lehet.

A fentiekben említett gondolatok mellett az alábbi táblázatban foglaltam össze vázlatosan azokat a tényezőket és feladatokat, melyek megítélésem és szakmai tapasztalataim szerint többségében általánosan figyelembe veendök és végrehajtandók.

\section{2. táblázat A terrorcselekmény különbözö fázisaira történö felkészités feladatai}

(Szerkesztette a szerzö)

\begin{tabular}{|c|c|c|}
\hline IDÖSZAK & FELKÉSZÍTÉS & FELADATOK \\
\hline \multirow[t]{2}{*}{$\begin{array}{l}\text { A terror- } \\
\text { cselekmény } \\
\text { bekövetkezése } \\
\text { előtt }\end{array}$} & $\begin{array}{l}\text { Szakmai } \\
\text { felkészítés }\end{array}$ & $\begin{array}{l}\text { - saját szakterület elméleti és gyakorlati szakmai ismeretei } \\
\text { egyénileg - képzés, gyakorlat; } \\
\text { - saját szakmai feladatok ellátásának rendszere kötelékben } \\
\text { (együttműködés, kommunikáció) - képzés, gyakorlat; } \\
\text { - a gyakorlatban hatékony és gyors készenléti és riasztási } \\
\text { rendszer létrehozása, müködtetése; } \\
\text { - területi jelenlét (ha indokolt); } \\
\text { - eljárásrendek aktualizálása, vészhelyzeti eljárások; } \\
\text { - müveleti törzs, hatékony helyszíni irányítás rendszerének } \\
\text { létrehozása; } \\
\text { - összekötők felkészítése; } \\
\text { - speciális (a gyorsreagálású is idetartozik) szakmai csoportok } \\
\text { létrehozása, felkészítése }\end{array}$ \\
\hline & $\begin{array}{l}\text { Lélektani } \\
\text { felkészítés }\end{array}$ & $\begin{array}{l}\text { - a feladat lélektani aspektusa; } \\
\text { - szituációs éberség; } \\
\text { - helyzetfelismerés, döntéshozatal magas stressz-szint alatt }\end{array}$ \\
\hline \multirow[t]{2}{*}{$\begin{array}{l}\text { A terror- } \\
\text { cselekmény } \\
\text { bekövetkezése } \\
\text { közben, annak } \\
\text { folyamatában }\end{array}$} & $\begin{array}{l}\text { Szakmai } \\
\text { felkészítés }\end{array}$ & $\begin{array}{l}\text { - a fenyegetés mielöbbi lokalizálása, semlegesítése, felszámolása } \\
\text { (különleges műveleti erők, terrorelhárító szolgálatok); } \\
\text { - másodlagos, illetve további fenyegetések felismerése, } \\
\text { azonosítása, semlegesítése, felszámolása; } \\
\text { - speciális szakmai csoportok helyszíni tevékenysége; } \\
\text { - műveleti törzs, hatékony helyszíni irányítás; } \\
\text { - saját szakmai feladatok ellátásának rendszere kötelékben } \\
\text { (együttmüködés, kommunikáció); } \\
\text { - sebesültek, javak mentése, károk minimalizálása; } \\
\text { - terület zárása, az ott tartózkodó személyek kezelése }\end{array}$ \\
\hline & $\begin{array}{l}\text { Lélektani } \\
\text { felkészítés }\end{array}$ & $\begin{array}{l}\text { - a feladat lélektani aspektusa; } \\
\text { - szituációs éberség; } \\
\text { - helyzetfelismerés, döntéshozatal magas stressz-szint alatt }\end{array}$ \\
\hline
\end{tabular}




\begin{tabular}{|l|l|l|}
\hline IDÖSZAK & FELKÉSZíTÉS & FELADATOK \\
\hline $\begin{array}{l}\text { A terror- } \\
\text { cselekmény } \\
\text { felszámolását } \\
\text { követő } \\
\text { időszakban a } \\
\text { helyszínen }\end{array}$ & Szakmai & $\begin{array}{l}\text { - a terület biztosítása, az ott tartózkodó személyek kezelése; } \\
\text { - sebesültek, javak mentése, károk minimalizálása; } \\
\text { - információgyűjtés; } \\
\text { - helyszín állapotának rögzítése, átadása a nyomozó szervek } \\
\text { részére }\end{array}$ \\
\cline { 2 - 3 } & $\begin{array}{l}\text { Lélektani } \\
\text { felkészítés }\end{array}$ & $\begin{array}{l}\text { - a feladat lélektani aspektusa; } \\
\text { - szituációs éberség; } \\
\text { - helyzetfelismerés, döntéshozatal magas stressz-szint alatt }\end{array}$ \\
\hline
\end{tabular}

\section{KÖVETKEZTETÉSEK}

Összességében megállapítható, hogy az elmúlt évtizedekben egy újabb fordulóponthoz érkeztünk a terrorizmus arculatának történeti alakulásában, a terrorcselekmények tervezésében, előkészítésének mechanizmusában és végrehajtásában egyaránt. Ez természetesen hatást gyakorolt a terrorizmus elleni küzdelemre, így a terrorcselekmények megelőzésére, elhárítására, felszámolására létrehozott egységek, szolgálatok fö és járulékos feladatrendszerére, valamint mindazon egyéb szervezetek tevékenységére, amelyek érintettek lehetnek egy ilyen cselekmény hatásainak elhárításában, a sebesültek mentésében, anyagi javak megóvásában.

A terrorizmus jellemzőinek változásai, a jelenlegi és várható tendenciák figyelemmel kísérése, elemzése és értékelése továbbra is fontos lesz a szakmai felkészítés hatékonyságának fenntartásában, javításában.

Lényegesnek tartom, hogy minden érintett rendelkezzen olyan felkészülési és végrehajtási tervvel, eljárásrendekkel, amely stabil alapot jelent egy gyors, meglepetésszerủ terrortámadásra adható hasonlóan gyors, megfelelően kiterjedt, komplex reagálás képességének kialakítására és fenntartására, tehát a megfelelő védelem biztosítására.

Ennek a képessége csak mindenre kiterjedő tervezés, folyamatos képzés és állandó gyakorlás, továbbá a gyakorlati életbe történő adaptálása során valósul meg, és talán az is kijelenthető, hogy nagyobb fontossággal bír, mint az eddigiek során valaha.

\section{FELHASZNÁLT IRODALOM}

Ágh Attila: Konfliktusok, háborúk. Zrínyi Kiadó, Budapest, 1989.

Az Európai Unió Terrorizmusellenes Stratégiája. Brüsszel, 2005. 11. 30. https://data.consilium.europa. eu/doc/document/ST\%2014469\%202005\%20REV\%204/hu/pdf

Kis-Benedek József: Dzsihadizmus, radikalizmus, terrorizmus. Zrínyi Kiadó, Budapest, 2016.

Kiss Zoltán László: A terrorizmus elleni küzdelem szociológiai természetü kihivásai. Hadtudomány, 2005/4., 182-187. http://mhtt.eu/hadtudomany/2005/4/2005_4_31.html

Netanjahu, Benjamin: Harc a terrorizmus ellen - Hogyan lehet legyözni a nemzetközi terrorizmust. Alexandra Kiadó, Budapest, 1995. 